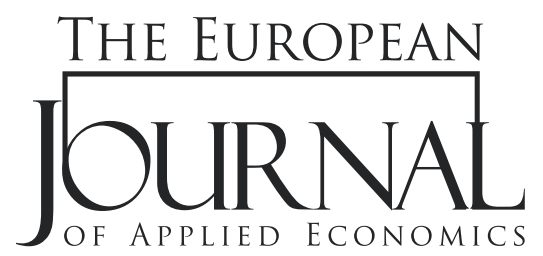

EJAE 2019, 16(1): 59-76

ISSN 2406-2588

UDK: 336.71:[004:007

336.71:[621.395.721.5:004.77

DOI: 10.5937/EJAE15-18751

Original paper/Originalni naučni rad

\title{
DEFINING THE NEED FOR AND PROPOSING HOW TO TRANSFORM TRADITIONAL INTO DIGITAL BANKS WITH THE SUPPORT OF INFORMATION AND MOBILE TECHNOLOGIES
}

\author{
Mirko Sajići,*, Zlatko Bundalo², Dušanka Bundalo³ \\ ${ }^{1}$ Sberbank a.d., \\ Banja Luka, Bosnia and Herzegovina \\ ${ }^{2}$ Faculty of Electrical Engineering, University of Banja Luka, \\ Banja Luka, Bosnia and Herzegovina \\ ${ }^{3}$ Faculty of Philosophy, University of Banja Luka, \\ Banja Luka, Bosnia and Herzegovina
}

\begin{abstract}
:
The need to practically and effectively implement the transformation of standard traditional banks into digital ones and how to transform them using information and mobile technologies are analyzed and described in the paper. The aim of this paper is to provide clear evidence about the need to transform banks from their present, traditional form into a new one that organizes and provides services, through a so-called digital bank. The great influence of mobile digital information technologies on the entire financial sector is further emphasized. The problems that appear because of the divergence of the existing concept of bank development and way in which modern clients want to obtain services, according to the possibilities of modern mobile digital technologies, are additionally explained. Proposals are also given for how to practically perform these changes and transformations, together with reasons that require changes. The basic principles for transitioning banks from traditional to digital formats through the so-called hybrid transformation period are presented, and several concrete solutions are proposed.
\end{abstract}

Article info:

Received: September 2, 2018

Correction: October 18, 2018

Accepted: October 31, 2018

\section{Keywords:}

bank transformation, information and mobile technologies, traditional retail bank and digital bank, hybrid period of bank transformation, digital bank creation period. 


\section{INTRODUCTION}

It has been noticed and written about in professional and scientific literature that the expansion of information and digital technologies has greatly contributed to the rise of so-called uncontrolled banking. State institutions and governments are trying to strengthen their banking regulations through their agencies for banking, but the achieved effects have not shown great efficiency. More and more often theses like the following can be found: "The banking system has been turned into a dysfunctional public-private project. Banking institutions achieve a huge profit by taking excessive risks in good times, while the government absorbs their losses in bad times." (McMillan, 2014).

Modern technology has drastically changed entire areas of life and interest of human population, of creation, of trade, and so on. One only needs to notice what happened to books (from their writing and publishing to how they are sold), what happened to bookstore chains (for example, Barnes \& Noble). Something similar happened to the music industry (for example, LP, cassettes, CD players, mp3 players, iTunes) and to movies and TV. A very similar situation is now also occurring with banks and in the banking sector.

The modern information, telecommunication, and mobile technologies lead to the fact that the modern banking client wants and demands that banks be faster, more efficient, and cheaper. Modern clients also wants that he/she realize his/her needs for banking services from his/her home or work, without needing to personally enter into bank premises. All that forces banks to be adapted to such requests and needs. However, all this in practice goes quite slowly and unorganized, without any systematic approach. This paper analyzes, proposes, and describes a systematized approach to transforming standard traditional banks into modern digital banks. It could contribute to a faster and better quality of practical transformation of banks and their adaptation to modern trends and client requirements and needs.

\section{DISHARMONY BETWEEN DEVELOPMENT OF BANKS AND MOBILE INFORMATION TECHNOLOGIES}

It is a well-known fact that it is very difficult for traditional banks to adapt to the growing expansion of the use of mobile digital technologies and mobile devices. Banks were one of the leaders in introducing new technologies in the time when the first computers, servers, databases, and communication links appeared. However, reception of the latest expansion and boom in the development and use of digital mobile technologies and mobile devices banks was quite unprepared (Turban, McLean \& Wetherbe, 2004; Accenture, 2015).

Figure 1. demonstrates the nearly identical matching of the structure of a traditional bank information system (Figure 1a.) and the structure of the bank itself (Figure 1b.) when client-server architecture was actual information technology. That structure is with the central office and the network of branch offices, agencies, and forward (remote) work places.

The main reason behind the banks' unpreparedness and delay concerning the speed of development and introduction of information and mobile technologies lies in the traditional form of structure of the so-called Retail Bank. A real existing example of such an structure is shown in Figure 2. It is not possible to adapt such an structure, with small changes, to new technology in such a way that the technology could be used to its full capacity and taking advantage of the possibilities they provide (Sajić, Bundalo, Bundalo \& Pašalić, 2017). The base of the traditional bank consists of the Central Unit (Central Office), which includes the strategic and operational management of the bank, IT (Information Technology) centre, marketing, the Call Centre, the Back Office, accounting and controlling, legal services, and other support services. The Central Unit dictates work procedures, creates and launches products on the market, and manages network operations. The network consists of relevant branches, agencies, 
and counters. This network was recently was expanded to include ATM (Automated Teller Machine) and POS (Point Of Sale) devices. That, in a sense, represented the limited use of modern technologies. The main problem of such forms of bank structure lies in the fact that modern clients, using modern mobile information technologies, mobile smart phones and tablets, receive an increasing amount of information and services through these mobile devices. As such, the need for clients to personally enter banks for services continues to disappear. On the other hand, the basic concept behind traditional banks is to attract clients to come into their bank branches and offices.

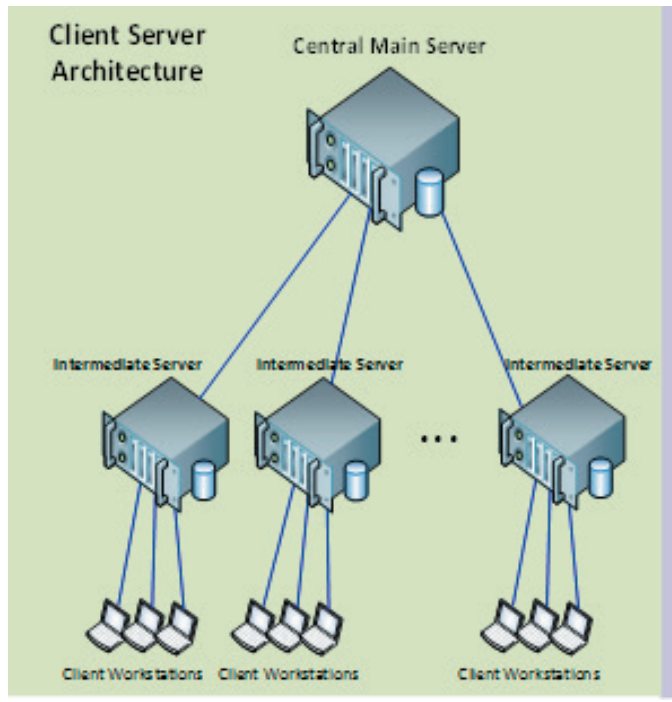

a)

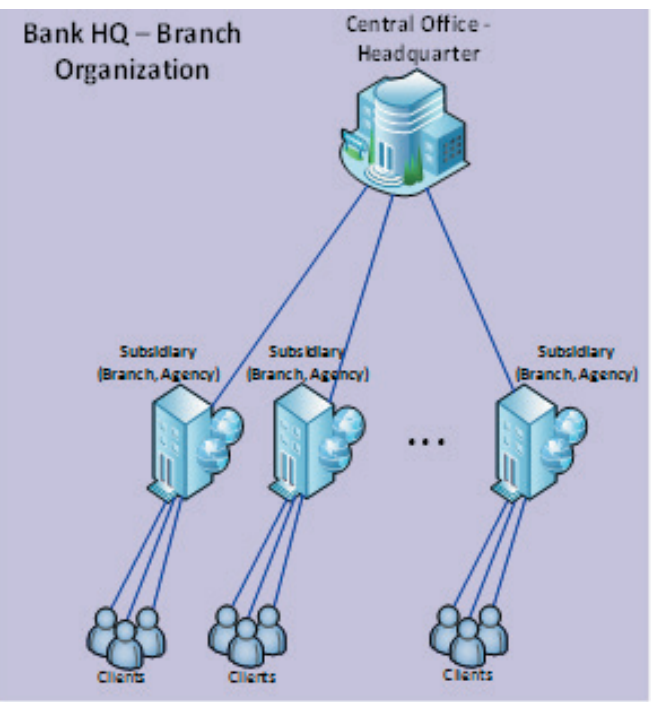

b)

Figure 1. Similarity of client-server architecture (a) and network structure (b) of bank

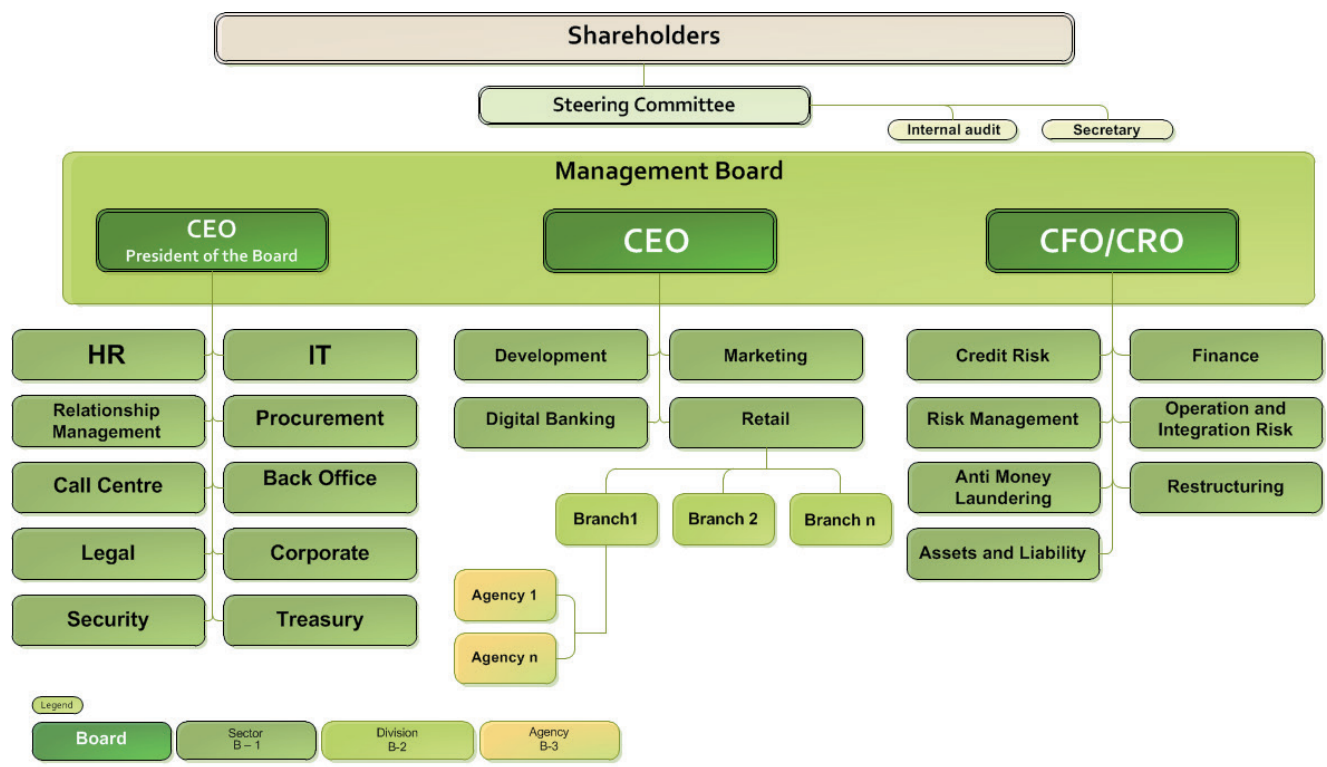


Banks have tried to use modern IT technologies, but quite incorrectly. Banks send e-mails and SMS messages to clients and publish a variety of information on their websites. Yet all this is done to attract clients to enter their offices. That is a real problem of this approach. Modern clients would like to obtain the banking services they need on their mobile devices and that they can realize these services from home, from work, while traveling, etc. However, the basic concept of a bank is still to do everything to attract clients to come into their office and to present and sell their banking products to clients there.

Banks have begun to develop and provide electronic (eBanking) and mobile banking (mBanking) services as products in order to somehow follow in line with their clients' desires and needs. .Products, when sufficiently popularized and distributed, demonstrate the thesis is correct of thesis concerning the way the structure of banks is outdated. Clients can perform many services by using their mobile devices. It practically demonstrates that the bank network of branches, agencies, and remote counters becomes unnecessary in the form that it is now. The simplest cost/benefit analysis would show that branch offices are more and more expensive, and that they are becoming less and less profitable. Clients' habits of are increasingly moving in other directions. The only thing that still retains branches in practice is the legal regulation of the Banking Agencies. They still require a client's physical presence in the realization of certain banking services (physical identification, signature on paper, etc.).

Figure 3. demonstrates the typical architecture of modern banks and a block diagram of the information system of a modern bank. In addition to the central area, essentially two channels, those of communication and bank operation performance with clients, physical channel and mobile channel, are shown. Physical contact with clients is realized through the network of branches/agencies/counters where there is physical personal contact between bank employees and clients. Through personal conversation, clients request and bank employees provide needed services. On the other hand, a number of clients access banks via the Internet, and use their mobile devices at their disposal. They perform their operations with the bank through the appropriate software support. Though not specifically shown here, ATM's and the network of POS devices basically belong to this group.

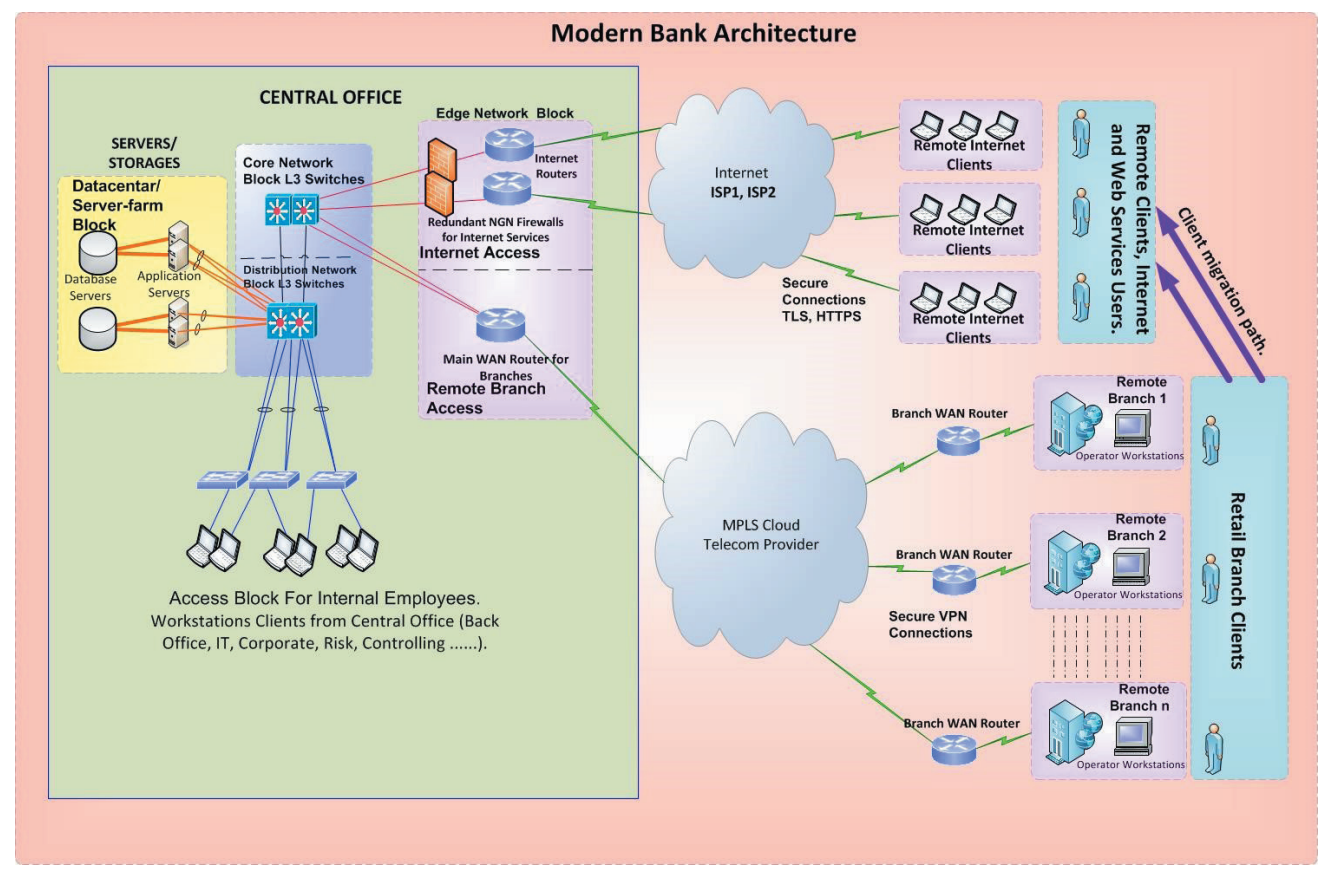

Figure 3. Typical architecture and block diagram of information system of modern bank. 
Figure 3. clearly shows that, during the time in question, more and more customers will use remote access with the help of mobile devices for performing banking operations. The so-called Client migration path can be seen in Figure 3. As such, there will be more and more weaken power and importance of using certain branches/agencies/counters and of parts of their networks. Based on this, it can be concluded that the networks of branches/agencies/remote counters will collapse by themselves when a sufficient number of clients begins to use almost exclusively work with bank at distance. It will happen under pressure of insolvency if before of that is not performed bank transformation, adequately and on time.

Prediction and proposal is that this will lead to transformation of complete banking network and transformation of purpose of its physical locations. In that process, some of that places will be converted into combination of devices for self-service during performing banking operations and reception offices. That offices will serve as suitable places where trained bank employees will perform work of banking financial advisors to clients who want to do this via physical contact and who need this kind of help. Some of that places will be completely closed. The latter is particularly related to rented places, non-bank-owned places. It is clear that sustainability of certain locations in which bank branches/ agencies/counters are located, in terms of cost-effectiveness, will no longer be possible after migration of sufficient number of clients to mobile technologies.

That means that the main reason for banking problems during the migration from using digital mobile technology and during the transformation into digital banks is, in fact, that branch networks and agencies become unnecessary (King, 2012; Accenture, 2015).

Moreover, the traditional structure of the bank implies traditional way of dealing with clients. However, all analyses demonstrate that if success with clients is desired then in some way it should become part of them (banks should become part of clients). That is especially demonstrated on the basis of development of social networks.

\section{THE DISADVANTAGES OF THE TRADITIONAL APPROACH TOWARDS CLIENTS AND HOW INFORMATION TECHNOLOGIES HELP}

With the birth of high-quality CRM (Customer Relationship Management) solutions and the building of their own Knowledge Data Bases in banks it is evidently that orientation to financial data only is insufficient to provide quality banking services to clients.

One of the most common descriptions of the term CRM that can be found in the literature is:

"CRM - Customer Relationship Management is the harmonization of business strategies, structural structure and culture of company, information about clients and information technology, with the purpose that in all contact with clients satisfy their needs and achieve business benefit and profit. CRM can be understood as a set of tools for management of business and relationship with clients, that enable full connectivity of clients with all processes that are performed, from tracking orders, offers and contracts, to tracking working tasks. It also represents an integrated marketing, service and sales strategy that requires the common work of all departments of the company. This business strategy is based on the philosophy "the buyer is king" and focus is on the client. Management with relationship with clients is reflected through people, processes and information technologies. The tool that is used to achieve the goals of this strategy is CRM technology. CRM is not just a tool or solution, it is also a special model of thinking." (Haase, 2016). Figure 4. shows the basic principles of CRM (Haase, 2016).

Development of information and mobile digital technologies, in particular expansion of eCommerce sales via the Internet, was demonstrated to clients what are all possibilities and options in this regard. Customers now know that it is possible to buy television set, music devices, furniture, kitchen devices 
via the Internet. Then, customers correctly thing why would not it be possible to get a loan in the same way to achieve a particular goal of retail shopping. Many of them are thinking even further, why not perform entire retail shopping in this way from one place and immediately. It is realistic to predict that in the near future significant number of customers will perform complete purchase process from their homes or from their workplaces. For example, customer could purchase a car even though he/ she did not even sit in it.

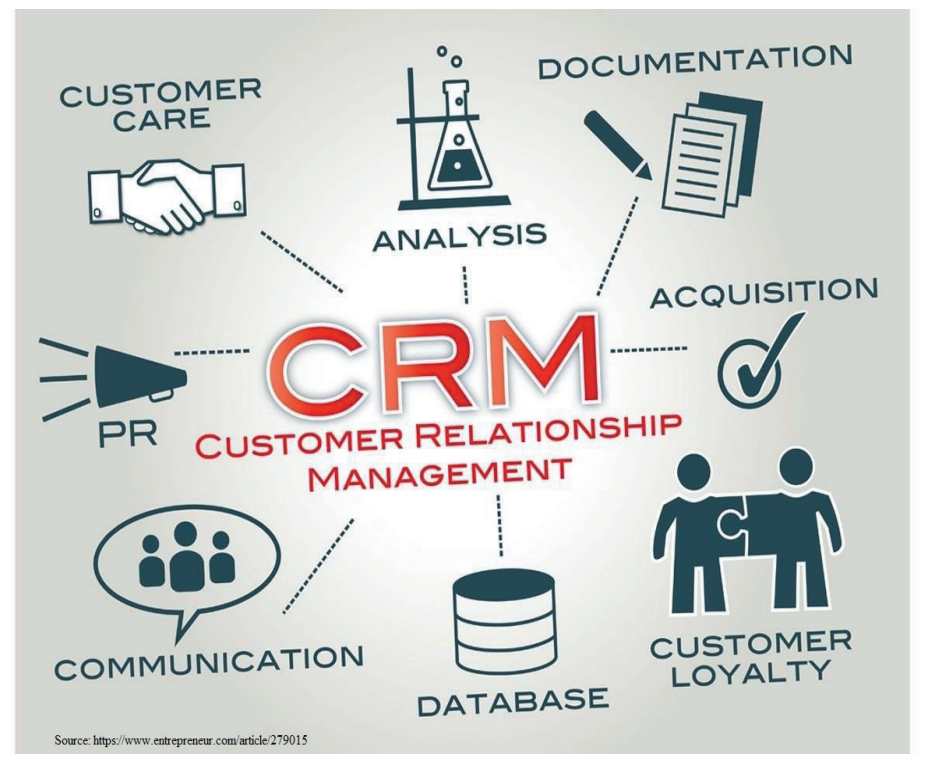

Figure 4. Basic principles of CRM.

The Knowledge Data Bases have been incorporated in large banks in last ten years or more (Turban, McLean \& Wetherbe, 2004; Accenture, 2015). They were originally intended to provide promptly and efficiently answers to questions asked in the structure (in the bank). However, it was appeared idea that this knowledge base, which every day increases and becomes more quality, can be efficiently used also in providing adequate answers to clients. For this purpose, with the help of so-called Business Intelligence, were made robots that respond to customers questions. It is most often performed on Web pages, although there are also cases of developed and used speech robots. Therefore, modern client raises very logical question that if this was possible to create and organize what is with possibility of automated loan offering and granting and with other automated banking services.

Proposals what should be performed in this regard in order to reduce lacks of traditional approach and to use possibilities of modern information technologies:

- Collect data from all available resources

It should be collecting data from all resources, especially on the Internet. Collect data such as data that can be found on social networks and various other resources. That should be data that contain information about existing but also potential clients. Locally it could be CIPS, Statistics, APIF, Registry of loans, data bases of water supply companies, electricity distribution companies, local telecom providers, etc. That data should be processed well. Organize own data bases, based on the Big Data concept, and connect them to existing CRM solution in order to obtain 
as much as possible useful client data. Such could better organize services and create products that will satisfy customers as much as possible. Based on that knowledge, choose appropriate products for appropriate user groups, address them appropriately, and perform predictions of their wishes and needs.

- Understand the power of mobile systems

Power of mobile systems could be illustrated, for example, with the information that the Barclays Bank needed 13 years to collect 2 million clients in its Internet banking application and only 2 months for the same number of clients on the mobile application.

- Understand the power of social networks

The most banks not only do not use social networks, such as are for example Facebook, Twitter, etc., but intentionally avoid them. That is practically big mistake. On the contrary, banks should stimulate "chatting" through that social networks. They should to open their accounts and profiles on social networks and to obtain their followers. In that way banks would easier perform marketing and expansion of information about their products. Also, those followers and others who would give their comments on social networks can serve to bank, especially to department for new products, as free of charge but very powerful testers of new products. It could be also performed surveys on existing products, collection of helpful advices for improving products and services, and similar.

But, it should be very careful that all this be performed in accordance with relevant laws and regulative about personal data. For example, the GDPR (General Data Protection Regulation) is regulation of European Union that prescribes way of manipulation with personal data of citizens (EU Regulation 2016/679) (European Parliament and Council of Europe, 2016).

\section{THE INFLUENCE OF SOCIAL NETWORKS ON THE DEVELOPMENT OF BANKING PRODUCTS}

Large modern companies, such as Google, Apple, Facebook and similar, with their approach and appropriate social networks, achieved that clients share their information with others.

Banks are either not trying to participate in social networks, or are doing it in a rather rigid and incorrect way, trying to control them. It has a bad effect for banks. Banks should stimulate engagement and the openness of their clients in order to obtain as much and as precise information as possible from the clients for the banks' own needs.

Below is a proposal for what should be done in order to use social networks to significantly improve bank operations:

- Harness the power of the masses by organizing surveys about their own current and future banking products

Use mass of bank active and potential users present on social networks for testing and as source of future ideas. Such, it is simply possible to bank to convert that mass of clients into a kind of department for new products, the department with great efficiency and with small investments. But, wrong approach to that mass of clients can cause loss of clients confidence, permanently or for a longer period of time. Therefore, all this should be performed very systematically and very responsibly. 


\section{IMPROVING KNOWLEDGE AND SOCIALIZATION OF CLIENTS USING MODERN INFORMATION TECHNOLOGIES}

Let us consider the following situation. Let someone is bank client for 10 years and they ask him/ her in the bank for name of his/her father. Two problems may arise in such case. The first problem is that, on the basis of a rigid too formal approach, it can be provoked reaction of the client of type "Why are you interested in that?". On the other hand, many companies such as are Google, Amazon, Apple, Facebook, Instagram, LinkedIn and others, already know this information for long time period. They were properly and unobtrusively obtained that information from the user, mainly through a hidden question when creating user names, passwords, and similar. Another problem, possibly even bigger, could be client reaction of style: "I am your client for ten years and you do not know anything about me. You asked me this question many times." Thus, the client correctly concludes that this bank does not care about him/her. His/her natural reaction is to look for another bank what will be better financial advisor for him/her. It is evidently that companies Google, Amazon and similar companies know more about us than the banks in what we are clients. It is clear that the problem is in the technology of approach and access to the clients.

Proposal what should be performed to better use knowledge and socialization of clients and modern information technology to improve bank operations:

- Change behaviour towards the client, be more accessible and open

It should allow even more relaxed way of bank staff dressing in order that also in this way be closer to clients. A rigid, repulsive and too formal approach and treatment towards clients refuses them and certainly does not contribute to the trust and closeness with bank, that the modern client is looking for. One of examples is way of dressing of bank staff, suit, tie, and similar. Analyses show that this generally could influence more refusing than that it attracts modern client. Also, it is needed to look more in the eyes of the client during contact and less to look at computer screen to concentrate on correct data entry. However, in order that bank employee be able to perform all of mentioned in a quality way, it should be enabled to him/her by technology. The bank should strive towards appropriate so-called "Front End" solution (an application used by bank employees when serving client). That solution should to allow that with a few movements of mouse employee can find and enter appropriate data, that use of keyboard be as less as possible, that the application itself offers appropriate products according to characteristics of specific client that adequate CRM will get either from CBS (Core Banking System) or from Big Data system.

This means that banks needs to know their clients, and to use the KYC (Know Your Client) principle. There is no bank that does not insist on it. But the big question is whether it is the right way it wants to perform it.

Proposal what should be performed to better know bank clients in order to improve operations of banks:

- Gain more knowledge about clients through sophisticated built CRM solution, based on Data Warehouse and Business Intelligence (Sajić, Bundalo, Bundalo \& Pašalić, 2017)

The main goal is to have accurate and on time information about client, both financial and nonfinancial, about his/her needs, wishes, and even also about his/her behaviour. That will enable necessary information to those bank employees who come at the counter in contact with the client, as well as to those who work on segmentation, who create and realize campaigns, according to which they will act towards client in an adequate way. Also, it should enable to those clients who want their activities with bank to perform remotely, by mobile devices, from home, from work, when are at travelling, to can perform it in such a way. 
It should be also used possibilities of so-called socialization of clients. It means that it should be find ways how to convince client to believe that bank employee will offer him/her the best solution.

Proposals what should be performed to better use possibilities of socialization of clients in order to improve operations of banks:

- Create mutual trust

It should be understood that power of the Internet and mobile devices is such that client can to obtain adequate information, in a very simple way, very quickly, almost on the spot, about same or similar products that are offered to him/her from other banks. This practically means that it should be offered products to client with reasonable prices and other conditions. It should not try at any price that product be sold to client, especially when it is known in advance that client will not use it and that product is not suitable for client. In practice it is very often case with sale of the package products. Managers in banks should stop practice of stimulating sales of products at all costs. For such attempts of sales, on the contrary, they have to determine penalty counter-measures. Client will realize that bank sold him some product unnecessarily, that he/ she does not use it, but pays as is using it. Client will then feel cheated and perhaps decide to change the bank. That is very often case in banking, selling products without previous analysis of needs of clients. The most common case is with electronic payment cards where to client are issued and sold, for example, both Visa and Master credit cards, but client uses only one of the cards. Similar situation is also with issuing and selling revolving and instalment cards that are usually not used by client. Very similar things were also done by mobile providers who offered the package services. They were, for example, to user who is their client for about decade or more in the package among others offered up to 3000 SMS messages per month. But, if they were performed statistical analysis of amount of messages that client sends monthly they would see that it was only about 10 .

- Stop practice of treating clients as they are goods, but try to satisfy real needs of client

When bank obtains customer trusts in such a way then it can count on long-term cooperation. Client will not leave bank so easily just because someone else offers some more financially favourable services at a certain moment, because the trust is created for years.

\section{TRANSFORMATION OF BANKS AND THE INCREASED NEEDS OF CLIENTS}

The most surveys that are carried out and that can be found in literature show that younger clients mostly say that banks do not know their needs. Also, the elder population of clients is not satisfied with degree of assistance of bank in creating their financial needs and strategies. As one recent and interesting example of that can be seen conclusion of one study. According to research of Cisco company with the title "Reimagining Digital Bank" it can be seen that $43 \%$ of clients in USA believe that their bank does not know them and therefore cannot provide them personalized service. In addition, 31\% of clients believe that their bank does not help them to achieve their primary financial goals. Also, 20\% of examined said that they will change banks and traditional financial institutions with personalized services of so-called "Internet of Everything (IoE)" type.

Proposal what should be performed to better coordinate activities of banks with growing customer needs:

- Accelerate transformation of banks

Accelerate bank transformation even at cost of achieving worse financial results in transformation period. That could be problem if owners of bank do not take clear position about the transformation. It is well known that owners of large number of banks are small shareholders 
and that there is no one recognizable owner who would have significant number of shares. That is more common for European banks than for US banks. The problem with banks with such type of capital could be when it is necessary to influence on Bank Management to begin faster transformation. Namely, mandates of Bank Managements are mainly on 4 year period. For such large bank transformations as is the one proposed and described here 4 years is short period. Also, effectiveness of success of existing Bank Management is measured in the period of their mandate. Therefore, any Bank Management will very difficultly and unwillingly decide to go on more radical transformation moves what may give worse results in initial series of years, even if later successes would far exceed previous temporarily weaker results. That really slows down processes of transformation and can lead banks to large problems. It is therefore necessary to look for effective ways how Bank Managements could be free of existing fear and be stimulated to accelerate unavoidable processes of bank transformation.

\section{MODERN RETAIL}

Modern retail of products and services, such as are performed by big companies Apple, Amazon, Google, eBay, etc., no longer implies only sale in the stores. It implies also use of such stores as means of creating followers of a brand, creating loyalty and belonging to a particular brand. Philosophy of so-called physical presence in the store is more and more becoming an outdated category, economically unprofitable and unsustainable, especially when products are becoming more and more "virtual." Practice of obtaining new clients at all costs, while neglecting keeping of existing ones, returns to banks as a boomerang. Modern IT solutions, advanced CRM and Front End solutions, mobile applications, Big Data and similar, and modern tools for achieving KYC approach are needed for keeping clients and obtaining clients loyalty.

It is necessary to maintain close relationship with existing clients and to increase total number of clients. This can be achieved by mobile applications, remotely. It is proposed that it be accomplished in the following way:

- Working, as best as possible, and as profiled as possible, on the segmentation of clients It should be performed with help of Big Data, social networks and strategies of addressing to different groups of clients,

- Working on permanent improvement of speech robots

Robots that answer on clients questions (so-called Chat boot) should be permanently developed and improved,

- Gathering in the Call Centre experts for the products

That experts should to answer live to clients by chatting, video and phone calls or postponed by e-mails, video help clips, etc.

\section{MODERN BANKS AND THE CONCEPT OF THE DIGITAL BANK}

The main task of standard Retail Bank in the past was to distribute live money (so-called cash) through network of bank branches. The basic task of modern bank now is ability to be constantly on service to customers with all bank products on the principle of availability of 24/7/365 basis.

It can be shortly said for fully digital bank that the entire banking business that bank has in its scope of activities digital bank performs in the cloud, via the Internet. There are no offices (physical places and locations) in what the bank would receive and serve clients. Accessibility of the bank and services 
is permanent and really of 24/7/365 type. Many banks, still traditionally oriented, usually post on their Web pages information about availability of 24/7/365 type. But, it is only partially correct and is valid only for certain types of services and products.

Mobile phones and other types of mobile devices are no longer just technological fashion trend. They are means that connect people on distance, that connect friends, relatives, business partners. Thus, the mobile devices become unavoidable also as means for realizing of banking operations. It is obvious that the mobile devices will very soon become primary means for realizing banking operations, as in some spheres of human activities they already are. Also, it is obvious that thus bank also will soon become digital bank (Marous, 2013; Accenture, 2015).

The digital bank is partly also social bank (Skinner, 2014). For example, it is interesting how many newspapers are being purchased and reading in this time. It is clear that this is less and less because their news, while they be printed and reach users, are mostly already out dated and worthless. Various types of Internet social mobile media have already published them. The social media long ago do not exist and live from subscriptions and similar things. They mostly serve to stimulate clients engagement and activities, through which, most often in an indirect way, they come to financial benefit. It is, therefore, clear necessity for digital bank to be connected with social media and social networks in finding useful information and in finding some of future ways for realization of financial earnings and profit. So, there is need to create links between banks and various social networks in order to exchange useful information and to obtain new useful information and knowledge about clients and groups of clients.

Banks can use social media and social networks in different ways:

- As a sources of information about clients,

- As a sources of information about different trends,

- As a polygon for testing of new ideas and new products,

- As a polygon for development of new products by launching information about new products and gathering reactions and opinions about it,

- As a place for popularization of their products and services

However, bank should here act with extreme care because social media were proven as very powerful in popularizing of any topic. So, it should take care not to get the reverse effect, not to start an avalanche of bad criticism on account of services and products of the bank, what could have great negative consequences for that bank,

- As a source and an example of new ways of performing operations and providing services.

\section{TRANSFORMATION OF BANK STRUCTURE AND ROLE OF MOBILE INFORMATION TECHNOLOGIES}

Development and application of information technologies significantly influence on needs and way of transformation of bank from traditional into digital one. It is clear that this will also cause significant changes in structure of bank.

It is proposal here and it is also expectation that in process of transformation the structure of banks should be transferred from vertical to horizontal one. Therefore, it is proposed here that in structure of bank should be performed transformation of sectors and departments into teams, organized and gathered around individual banking products. The teams should look more like project teams than like current banking sectors. There would be very few workers outside of these teams, mostly common services and management. Figure 5. shows proposed model of structure of modern digital bank. It is more similar to some production structure than to the current bank (Sajić, Bundalo, Bundalo \& Pašalić, 2017). 
With banking experts for each particular product in the teams will also be experts from IT technologies who are connected with that product, experts from so-called data science, experts for marketing of that product type, experts from Call Centre. Proposal is that, with all of them, in the team also be engaged mathematician/statistician and psychologist/sociologist. They should statistically and psychologically/sociologically shape and from the expert point of view interpret obtained data. Based on that they will propose guidelines to the marketing and others in the team.

It is clear that in the transformation of structure of bank the IT sector will also go through significant changes. It is proposed here that the most part of the IT sector be simply divided by product teams. As some specific sector or department it should remain technicians/operators and administrators who work on general activities (e-mail, the Internet, active directory environment, etc.).

It is also evident that in such new structure of digital bank outsourcing of the IT sector becomes impossible. It should be already clear to everyone that technology on what are based all more important jobs and work places in the bank can not be outsourced. IT sector for long time is no more bank service but it acts more like its bloodstream. It may sound strange but it is easier to outsource the Corporate part of bank than the IT part. Something just like that will most probably happen in near future. For example, the banks for what it will no longer be profitable will transfer business of payment transactions to someone else with whom they will make contract. It could be for example some FinTech company, PayPal for example. However, it is absurd and impossible to expect that bank can perform outsourcing of operations of IT sector in the future. If the bank would even succeeded to do it, having in the mind nature of digital bank and ways of its operation, nothing more would prevent such an outsourcing partner from becoming bank itself, because it was already taken over all important bank jobs.

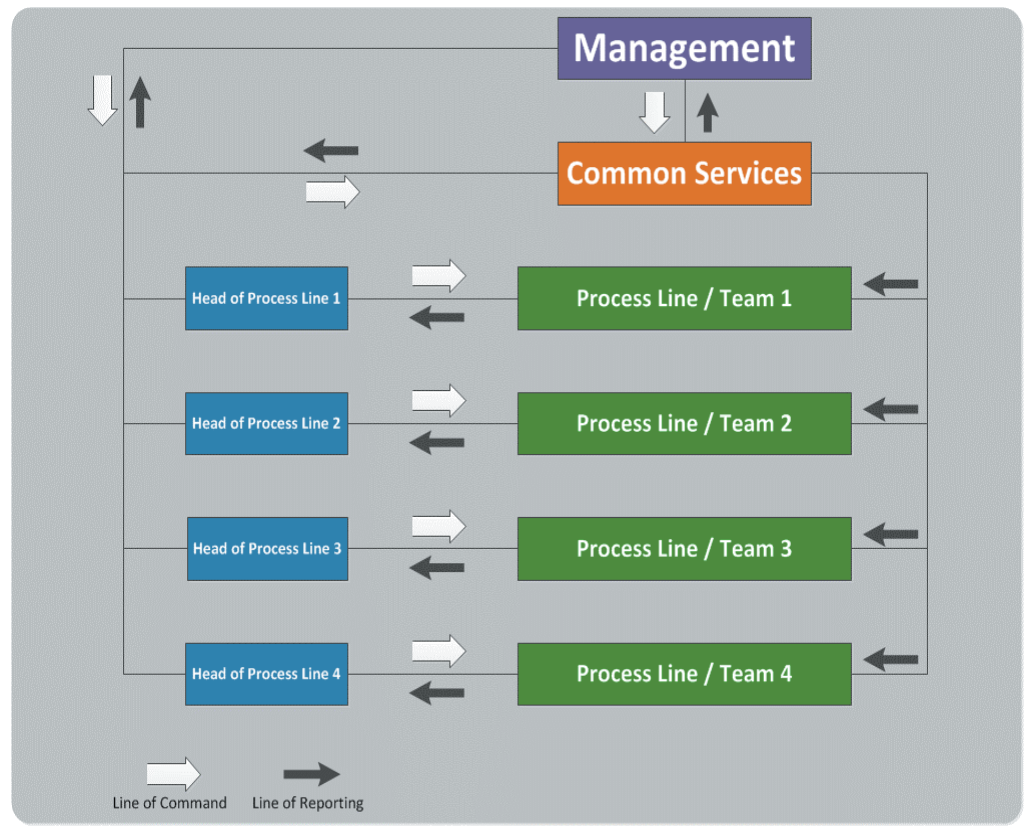

Figure 5. Proposed model of structure of modern digital bank.

Also, it is evident and clear that the Bank Managements in the modern digital banks will have to have IT experts in their composition. Or the Bank Management will post them as so-called Chief Information Officers. They will not formally be in the Bank Management but will have authority as well 
as the Bank Management in the areas of IT technologies that they cover. It is already evident in present banks that there is huge lack of IT experts, especially in part for organizing and performing projects. The great majority of banking projects as a very significant have IT component. That creates difficulties for those who initiate, organize and implement projects but do not have necessary IT knowledge. When such project comes to the head of IT sector it is usually then too late to correct created errors. Also, the head of IT sector does not have sufficient authority to impose an opinion that he/she considers to be correct based on his/her expertise and expertise of his/her team.

\section{MODERN BANKING APPLICATIONS AND CORE BANKING SYSTEMS IN THE FUTURE}

The biggest transformation in information technologies and in information system (IS) in bank will not happen either in interface nor in some special technology. It will be in approach which must enable easier anticipation of needs of clients and their habits and customs. It is proposed here that in the future it more goes to build such API functions that will be easily fitted into various heterogeneous systems. It is proposed that the IS of the bank be decomposed into the components, into the products. On the basis of it, the banks could be also profiled and could perform only some types of banking operations, that are profitable for them. With other jobs bank will not deal at all or will, through the API interface, connect with other banks or FinTech companies, specialists for that type of services. The bank will transfer them concrete work while taking its share of financial compensation in distribution chain. Only members of large banking groups will, maybe, remain to deal with complete banking operations as it is also situation now in practice.

Regarding the API functions, in one survey can be seen that $59 \%$ of banks declared that so-called "open API" technology will have great impact on modelling their products. Approximately $67 \%$ of banks stated that API already has an impact or that it is expected in the next 2 years. While $39 \%$ examined stated that they already allocate large percentage of investments in the implementation of API technology.

The proposal of structure of the IS of modern digital bank is shown in figure 6. (Sajić, Bundalo, Bundalo \& Pašalić, 2017).

It can be seen from figure 6 that here is proposed and predicted that communication with data that is coming from clients first realizes the CRM and then the CRM forwards data to the CBS. It is ensured in this way that the CRM in the real time analyzes incoming data and creates some conclusions based on it or only forward data to the CBS.

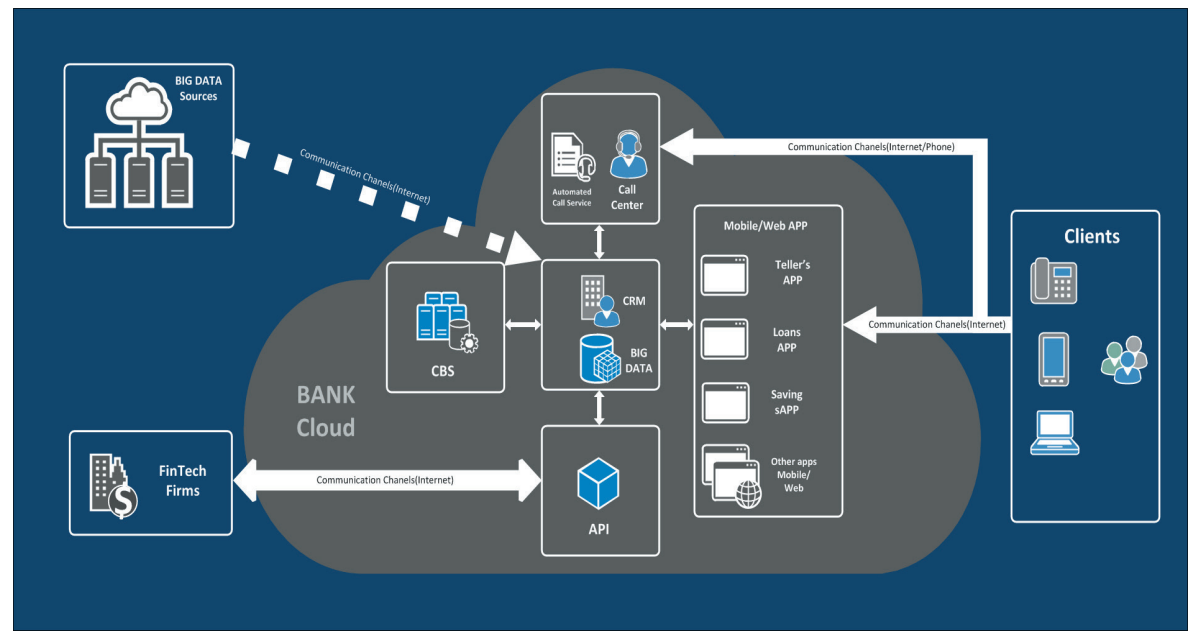

Figure 6. Proposal of structure of information system of digital bank. 


\section{PROPOSAL OF WAY OF BANK TRANSFORMATION FROM TRADITIONAL TO DIGITAL BANK}

In addition to already mentioned arguments that are caused by huge population of digital mobile technology and changes of habits and wishes of clients, there is also one more important fact why it is natural process of transformation of traditional into digital (cloud) bank. If it is looked carefully, it can be seen that almost all banking products and services have already become of virtual character. With withdrawal of "the cash" from circulation the last "solid" banking product is also lost. It is known that every virtual product and service can be algorithmically described and therefore software processed and automated (API functions). That is why a logical question arises in relation to fact that banks usually have large number of branches, most often in their possession. The proposed solution is in performing transformation of bank from traditional to modern (digital) bank. Intermediate phase in that would be so-called hybrid period.

One representative example of failed attempt of transformation is transformation of traditional banking branches into places for sitting, drinking coffee and talking about banking activities, according to model applied for bookstores. Clients that come into bank offices come with concrete intention and do not want to spend more time there than it is needed. They want as soon as possible to complete activities they have planned. They probably do not have enough time and have some other obligations. This is basic difference in comparison to similar, but successful, model of transformation of bookstores. Even some conveniences, such as free Wi-Fi, free coffee and similar, do not hold clients in bank more than it is needed. Simply, clients did not come with intention to relax but to perform necessary activity in the bank as quickly as possible.

It is proposed here one completely different way of transformation of bank branches. Some of reasons for that transformation are:

- There is less and less money in the branches, the money becomes data, and data must be centralized to be usable.

- Branches will be less and less sales and transaction centres, and more and more will become centres where consultations on more complex products are performed.

- The products of the bank, except of the cash, by their nature are virtual and then it is much easier to organize sales and perform services via the Internet.

Newly formed banks and small banks with a few branches will much easier perform transformation into hybrid or digital banks. Large banks will have many problems while be performing transformation. What banks are bigger the transition process will last longer. Some of the world largest banks are, probably calculating about needed time for transition, decided that for them is more profitable to create completely new digital bank that will appear on the market immediately. That bank will acquire part of new clientele that is already ready for such type of bank and prevent leaving of part of the existing clientele who will automatically move to the digital bank.

It is proposed that the process of bank transformation be divided into two periods: hybrid period (Weber, 2014) and period of creation of the digital bank, and that the process be realized in that order.

\section{Hybrid period}

It is proposed here that the hybrid period of transformation of banks includes the following phases and activities:

- Replace traditional banking counters in the bank branches with multifunctional ATM devices Besides issuing money that devices can also receive money, perform payments and can gradually increase number of banking services. At the start, it would be desirable that this devices have 
microphone handsets and ability to reproduce video clips that are essentially help reproductions. Such equipped that devices would be able at a later stage, when will no more be employees at place of installation of that devices, to have possibility for connection with the Call Centre for purpose of providing assistance and consultations to clients.

- Train employees to become consultants and providers of services

Train them to be more consultants and providers of services and less sellers of services.

- At places where the settings of described devices creates sufficient surplus of employees shorten working hours of employees and organize work in more shifts

It should be performed in order to provide as quality as possible and as approximate as possible services of the 24/7/365 type, and in order to keep as much as possible employees.

- ATM devices, located in separate locations outside the branches, attempt to transfer to ownership of specialized firms

Such firms will necessarily appear on the market and their primary business will be working with ATMs. It is already known that ATMs are becoming more cost than they itself earn. Reasons for that are increases in cost of renting space, insurance and transport of the money. If it is realized by one specialized firm, its costs will be the same or lower than for the bank, but it will be used the same device for several banks with which it makes contracts. On the other hand, bank will such expand its network of ATM services and at same time reduce costs.

- Transform branches and agencies into places to provide consultations

It should be performed for purpose of better selling products and raising level of bank services.

- Try to sell or rent selling places that appear insufficiently visited

It should try to sell or rent places that are non profitable in terms of contribution to the overall image and operation of the bank.

- Introduce and permanently upgrade CRM solutions in information system of the bank

It should be performed in order of better and faster segmentation of clients, connected in groups according to some characteristics and, accordingly, creating successful campaigns for purpose of selling and popularizing banking products and services. Good CRM solutions will enable more efficient usage of information about clients financial habits and achievement of KYC strategy in full sense of that word.

- Introduce and permanently upgrade DMS solution of the bank

It should be performed in order of more efficient archiving of banking documents, their faster searching and savings in physical space, paper and everything else that includes the archive in physical sense. DMS is very useful also for possibility of automating of banking jobs.

- Permanently work on the automation of banking operations

It should try to perform it in all parts of the banking business.

\section{Period of creation of digital bank}

It is proposed here that the period of creation of a digital bank includes following phases and activities:

- Synchronously with phases of hybrid period, strengthen centralization of bank with core in Call Centre

The reason for this is that through the Call Centre will be provided consulting and help services to clients. It will be performed either through educational video clips, by telephone, via live video, by chatting or by email correspondence. By contact via the Call Centre clients will be able to get 
answers on their questions and consult themselves from the first hand, from the most specialized people and experts related to the particular product. In the traditional bank system the client received information from the Account Managers or Personal Bankers, who went to trainings to mentioned experts. Although they can be very capable, they are still so-called second hand experts. Such, it is lost on the quality of presentation of a particular product.

- eBanking and mobile banking applications merge into one, at least as far as users are concerned The goal is that user when is using eBanking or mobile application not notice difference at all, that can to start at one and to end on the other, that training for using is the same for both, and similar.

- As tempo of harmonization of legislation will allow, change products and services in a way that they can be executed and used remotely

Products and services should also be transferred on mobile applications.

- Create a flexible information system

It should be performed through the API functions. It should be performed such that it be easily compatible with other applications, especially with those already offered by the so-called FinTech firms, because that firms are leading in innovative services. There are very few of banks that have such development teams that can parry to FinTech firms. If they have them, it is only in certain banking business domains. It is more profitable to have the ability to provide some service on time, than at all costs to develop it. The PSD2 EU directive supports this conclusion (Backbase, 2017).

- Reorganize bank such that it has far less vertical and far more horizontal elements

It can be seen in figure 1. problem and complexity of organizing cooperation between sectors in traditional bank, because all cooperation goes through the central parts. It is therefore necessary to reorganize current banking sectors (Retail, Corporate, IT, etc.) into more efficient teams concentrated around products or product groups. Only the most necessary personnel that serves to provide common internal services to that teams should be leaved in the vertical part of the structure. Also, very small number of managing posts that serve to effectively connect that teams into the structural unit should be in the vertical part. Programmers, development teams, marketing, sales teams should be grouped by that product teams. Thus will be provided narrow specialization of professional personnel, their greater efficiency and better teamwork. Such new proposed structure of the digital bank is shown in figure 5. (Sajić, Bundalo, Bundalo \& Pašalić, 2017).

- Introduce the "Big Data" concept into the information system of bank

It should be performed in a way to enable better collection of both financial and other data about clients of the bank, according to the model of the world known search engines, Internet shops, social networks, etc. For providing adequate services to clients, it is not enough only knowledge about the financial characteristics of the client but also other knowledge, especially related to its purchasing habits. So, it is necessary and desirable to perform as soon as possible transformation of banks from financial data banks into data banks. This will also cause employment of some of previously unused employee profiles in banks. Beside "data science" specialists that would be experts for Big Data, it will be need to classify and statistically process the data. Such, it opens places for profiles of employees of mathematician/statistician type and psychologist/sociologist (or of similar education) type. They will provide correct interpretations of statistically processed data.

- Permanently work on development and introduction of new banking services and products

It should be performed on application of information and mobile technologies (Sajić, Bundalo, Bundalo \& Pašalić, 2017; Sajić, Bundalo, Bundalo \& Pašalić, 2018; Sajić, Bundalo, Bundalo, Stojanović \& Sajić, 2018; Sajić, Bundalo, Bundalo, Sajić \& Kuzmić, 2018). 


\section{CONCLUSIONS}

The need for anticipated changes in the banking sector is no longer questioned. The way that this will be performed can vary in accordance with specifics of concrete bank. One general principle for transformation of banks from traditional into digital banks that is practically the most expected and the most realistic possible way is proposed and described in this paper. Tempo of implementation of all activities of the transformation will depend mostly on tempo of adoption of necessary legal regulations related to the digital business. Such regulations are digital signature and other similar regulations that will remove need for physical visits of clients to bank branches. Also, it will depend on degree of pressure of clients on banks for gaining ability to use bank services remotely. Proposal is that banks already now perform all activities that they are able to do in order to more prepared meet that changes. Also, banks should even to initiate that changes in accordance with their possibilities. Cooperation and symbioses of banks and telecom operators also have great chances to provide good results in these areas, especially in the case of local and regional structures.

The process of transformation will be more complex and slower if bank is more diversified, if it has larger network of branches and agencies. From that reason, some large world banks use another method in the transformation. They were established totally new digital bank. That digital bank in parallel with traditional bank operates on the market. It tries to satisfy all those clients who are already prepared to move to new way of operation with bank (remote operation). At the same time, they will also get some new clients from some other banks that still do not offer such conditions of operation. It is expected that, over time, this newly established digital banks will take over leadership of their traditional banks founders and that huge majority of clients will move over time to that new digital bank.

The trend among clients to complete the entire centralized retail business has become more and more noticeable. For example, a buyer wants to buy new kitchen. He/she wants that from one place select model of kitchen that suits to him/her and that at the same place resolves commercial conditions (to choose loan and perform payment). If banks do not set themselves as leaders in this process, someone else will set up and take over that business. Companies that have successfully developed social networks, search engines, and Internet shopping could become new retail leaders. Such companies have greater potential and possibility to take over the retail business and, therefore, retail banking in the future. Banks need to keep this in the mind, to develop their own appropriate strategy, and to transform themselves in that direction as soon as possible.

\section{REFERENCES}

Accenture (2015). Being digital: Digital strategy execution drives a new era of banking. Retrieved Jun 30, 2018, from https://www.accenture.com/us-en/insight-digital-strategy-new-era-banking

Backbase (2017). The PSD2 Playbook - Backbase. Retrieved Jun 30, 2018, from https://backbase.com/wp-content/ uploads/2017/04/Backbase_The_PSD2_Playbook.pdf

European Parliament and Council of Europe. (2016). Regulation (EU) 2016/679 of the European Parliament and of the Council of Europe of 27 April 2016 on the protection of individuals with regard to the processing of personal data and on the free movement of such data and on putting out of force of Directive 95/46/EC (General Data Protection Regulation). Retrieved Jun 30, 2018, from https://eur-lex.europa.eu/eli/reg/2016/679/oj

Haase, S. (2016). 4 unconventional ways to use your CRM software. Retrieved Jun 10, 2018, from https://www. entrepreneur.com/article/279015

King, B. (2012). BANK 3.0: Why Banking Is No Longer Somewhere You Go But Something You Do. Hoboken: Wiley.

Marous, J. (2013). Top 10 Retail Banking Trends and Predictionsfor 2014. Retrieved Jun 3, 2018, from https://thefinancialbrand.com/36367/2014-top-bank-trends-predictions-forecast-digital-disruption. 
McMillan, J. (2014). The End of Banking Money, Credit, and the digital Revolution. Zurich: Zero/One Economics.

Sajić, M., Bundalo, D., Bundalo, Z., \& Pašalić, D. (2017). Digital Technologies in Transformation of Classical Retail Bank into Digital Bank. In 25th Telecommunications forum TELFOR 2017. 21-22 November 2017 (pp. 1-4). Belgrade: Telecommunications Society.

Sajić, M., Bundalo, D., Bundalo, Z., \& Pašalić, D. (2018). Using Digital and Mobile Technologies for Increasing Efficiency of Financial Institutions. Acta Technica Corviniensis-Bulletin of Engineering, 11(3), 39-42.

Sajić, M., Bundalo, D., Bundalo, Z., Stojanović, R., \& Sajić, L. (2018). Design of Digital Modular Bank Safety Deposit Box Using Modern Information and Communication Technologies. In 7th Mediterranean Conference on Embedded Computing MECO 2018. 10-14 June 2018 (pp. 107-112). Budva: IEEE.

Sajić, M., Bundalo, D., Bundalo, Z., Sajić, L., \& Kuzmić, G. (2018). Programmable Electronic Payment Card Transaction Limit Implemented Using Mobile Electronic Technologies. In 7th Mediterranean Conference on Embedded Computing MECO 2018. 10-14 June 2018 (pp. 186-190). Budva: IEEE

Skinner, C. (2014). Digital Bank: Strategies for Launching or Becoming a Digital Bank. Singapore: Marshall Cavendish Business.

Turban, E., McLean, E., \& Wetherbe, J. (2004). Information Technology for Management - Transforming Business in the Digital Economy. Hoboken: Wiley.

Weber, M. (2014). 5 Tips for Your Next Branch Transformation Project. Retrieved Jun 5, 2018, from https://thefinancialbrand.com/39641/bank-credit-union-branch-design-tips.

\section{POTREBA I PREDLOG NAČINA TRANSFORMACIJE KLASIČNE U DIGITALNU BANKU UZ POMOĆ INFORMACIONIH I MOBILNIH TEHNOLOGIJA}

\section{Rezime:}

U radu se razmatra i opisuje potreba da se praktično i efikasno realizuje transformacija standardne klasične banke u digitalnu banku i način transformacije korišćenjem informacionih i mobilnih tehnologija. Rad ima za cilj da pruži jasne dokaze o nužnosti transformacije banaka iz sadašnjeg klasičnog oblika u novi oblik organizovanja i pružanja usluga, u tzv. digitalnu banku. Pri tome je takođe naglašen veliki uticaj mobilnih digitalnih informacionih tehnologija na celokupni finansijski sektor. Objašnjeni su problemi koji nastaju zbog razmimoilaženja postojeće koncepcije razvoja banke i načina na koji moderni klijent želi da mu se pruži usluga, shodno mogućnostima modernih mobilnih informacionih tehnologija. Zajedno sa razlozima koji zahtevaju promene, dati su i predlozi kako da se praktično izvrše te promene i transformacija. Predstavljena su osnovna načela prelaska banke iz klasičnog u digitalni oblik, preko tzv. hibridnog perioda transformacije, te predložena neka konkretna rešenja.

\section{Ključne reči:}

transformacija banke, informacione i mobilne tehnologije, klasična retail banka i digitalna banka, hibridni period transformacije banke, period stvaranja digitalne banke. 